\title{
Frequency of Leptospira spp. in sheep from Brazilian slaughterhouses and its association with epidemiological variables $^{1}$
}

\author{
Rodrigo Costa da Silva ${ }^{2 *}$, Veruska Maia da $\operatorname{Costa}^{2}$, Fabio Hiroto Shimabukuro ${ }^{2}$, \\ Virgínia Bodelão Richini-Pereira ${ }^{2}$, Benedito Donizete Menozzi ${ }^{2}$ and Hélio Langoni ${ }^{2}$
}

\begin{abstract}
Da Silva R.C., Costa V.M., Shimabukuro F.H., Richini-Pereira V.B., Menozzi B.D. \& Langoni H. 2012. [Frequency of Leptospira spp. in sheep from Brazilian slaughterhouses and its association with epidemiological variables.] Pesquisa Veterinária Brasileira 32(3):194-198. Departamento de Higiene Veterinária e Saúde Pública, Faculdade de Medicina Veterinária e Zootecnia, Universidade Estadual Paulista, Campus de Botucatu, Distrito de Rubião Júnior s/n, Botucatu, SP 18618-970, Brazil. E-mail: silva_rcd@yahoo.com.br

Leptospirosis is a worldwide anthropozoonosis that infects livestock, including sheep as the carriers to other animals and humans. The present study aimed to determine the prevalence of Leptospira spp. in sheep from two slaughterhouses in the state of São Paulo, Brazil and its association with epidemiological variables. Serum samples from 182 sheep were evaluated for Leptospira spp. antibodies by microscopic agglutination test (MAT). Results indicated 34/182 (18.68\%; CI95\% 13.70-24.98\%) positive serum samples, mainly to the serovar Copenhageni (17/34; 50\%; CI95\% 33.99-66.01\%). Bacterial growth in the Fletcher medium was detected for 13/34 (38.24\%; CI95\% 23.87-55.08\%) animals, and confirmed by Polymerase Chain Reaction (PCR) and sequencing for only two kidney samples from two animals. Thus, treatment and vaccination of sheep, besides rodent control, can be useful to prevent the infection in the studied region since sheep are important Leptospira spp. carriers, and its transmission to slaughterhouse workers is mainly through the manipulation of visceral tissues.
\end{abstract}

INDEX TERMS: Leptospira spp., sheep, tissue samples, isolation, PCR, slaughterhouse.

RESUMO.- [Frequência de Leptospira spp. em ovinos abatidos em matadouros brasileiros e sua associação com variáveis epidemiológicas.] A leptospirose é uma antropozoonose mundialmente distribuída que infecta animais de produção, incluindo as ovelhas como carreadores para outros animais e o homem. 0 presente estudo objetivou determinar a prevalência de Leptospira spp. em ovinos de dois abatedouros do estado de São Paulo e sua associação com algumas variáveis epidemiológicas estudadas. Amostras de soro de 182 ovinos foram pesquisadas para a presença de anticorpos para Leptospira spp. pela soroaglutinação microscópica (SAM). Os resultados indicaram 34/182 (18,68\%; IC95\% $13,70-24,98 \%$ ) amostras positivas, principalmente para o

\footnotetext{
${ }^{1}$ Received on August 30, 2011.

Accepted for publication on October 25, 2011.

${ }^{2}$ Departamento de Higiene Veterinária e Saúde Pública, Faculdade de Medicina Veterinária e Zootecnia (FMVZ), Universidade Estadual Paulista (Unesp), Distrito de Rubião Júnior s/n, Botucatu, SP 18618-970, Brazil. *Corresponding author: silva_rcd@yahoo.com.br
}

sorovar Copenhageni (17/34; 50\%; IC95\% 33,99-66,01\%). Crescimento bacteriano no meio de Fletcher foi observado em amostras de 13/34 (38,24\%; CI95\% 23.87-55.08\%) animais, e confirmados pela Reação em Cadeia pela Polimerase (PCR) e seqüenciamento para somente duas amostras renais de dois animais. Assim, o tratamento e vacinação dos ovinos, além do controle de roedores, pode ser útil na prevenção da infecção na região estudada, visto que os ovinos são importantes carreadores de Leptospira spp. para o homem, e sua transmissão aos trabalhadores de abatedouros ocorre principalmente pela manipulação das vísceras.

TERMOS DE INDEXAÇÃO: Leptospira spp., ovinos, amostras teciduais, isolamento, PCR, abatedouro.

\section{INTRODUCTION}

Leptospirosis is a worldwide infectious, emerging and re-emerging zoonosis caused by a spirochete of the genus Leptospira (Bharadwaj 2004), leading to epidemic outbreaks mainly related to specific activities (Trubo 2001, Bens- 
chop et al. 2009). Its main reservoirs are pets and livestock, primary hosts essential for the persistence of the infection focus. Humans are accidental or terminal hosts. Transmission through direct or indirect exposure to infected urine is usually associated with a specific season or environmental factors that facilitate this exposure (Lilenbaum et al. 2008). Leptospirosis may be endemic or epidemic for many species, including humans, especially in developing countries and/or in those of tropical climate (Horsch 1999, Bharti 2003, Sacsaquispe-Contreras et al. 2003, Martins et al. 2011).

Sheep are considered less susceptible to leptospirosis than other livestock species, such as cattle (Leon-Vizcaino et al. 1987). This anthropozoonosis can manifest in an acute form in small ruminants, causing pyrexia, anorexia, depression, jaundice, and anemic or hemorrhagic syndromes (Martins et al. 2011).

Leptospirosis causes economical losses in sheep due to abortions. In addition to the reproductive system, leptospires can colonize the kidneys, making sheep potential renal carriers. Thus, the bacteria remain in the environment and sheep may act as a source of infection for other animals and humans (Suepaul et al. 2011). Sheep become infected by contaminated urine from rodents, cattle or wild animals. (Dorjee et al. 2011, Martins et al. 2011, Suepaul et al. 2011).

In Brazil, leptospirosis has been scarcely reported for sheep concerning its etiology and spirochete isolation (Lilenbaum et al. 2007, 2008). Thus, the present study aimed to determine the frequency of Leptospira spp. in sheep from Brazilian slaughterhouses and its association with epidemiological variables.

\section{MATERIALS AND METHODS}

Study design. This study was carried out in two slaughterhouses (A and B) from São Paulo State. The collected serum samples were sent to the laboratory of the Center for Zoonosis Research (Nupezo), from School of Veterinary Medicine and Animal Science (FMVZ), São Paulo State University (Unesp), Botucatu Campus, SP, Brazil, for serological test.

Tissues from seropositive animals were evaluated for spirochetes by darkfield microscopy (DFM), cultured in Fletcher semisolid medium and assayed for Leptospira spp. DNA through molecular techniques. Positive samples were sequenced in the Human Genome Research Center, Institute of Biosciences, São Paulo University (USP), São Paulo Campus, SP. This study was approved by the Animal Experimentation Ethics Committee, FMVZ-Unesp, Botucatu Campus, SP (65/2006-CEEA).

Sampling. The software Epi Info 3.5.1 (CDC 2008) was used to determine the minimum number of samples (n), adopting $13.7 \%$ as expected prevalence (Lilenbaum et al. 2007), significance level $(\alpha)=5 \%, 95 \%$ confidence level and 6\% error limit, which resulted in $\mathrm{n}=124$ animals, adjusted to 182 animals. The present number was determined considering a Brazilian population of 253,500 slaughtered sheep in 2008, and of 8,300 in São Paulo State (3.27\%) (Brasil 2009, Sorio \& Rasi 2010).

Blood, kidney and liver samples were collected from sheep in two slaughterhouses belonging to the region of Botucatu $\mathrm{Mu}$ nicipality, SP, and receiving animals from the southern and southeastern regions of Brazil. Slaughterhouses did not present any planning by sacrifice animals by region. Some days they sacrifice animals from one region, other days from two or three regions.
The sampling was conducted by random selection of the animals in the slaughterhouse by day (one yes, one no). No clinical signs were presented. Blood samples were centrifuged at $1600 \times \mathrm{g}$ for $10 \mathrm{~min}$, and the serum was kept at $-20^{\circ} \mathrm{C}$ until the serological test. Epidemiological data such as animal age, sex, breeding system, and origin were also obtained.

Serological test. The presence of anti-Leptospira spp. antibodies was determined by microscopic agglutination test (MAT), with 28 different serovars: Leptospira interrogans [Australis (Ballico), Bratislava(Jez-bratislava), Autumnalis (Akyiami A), Bataviae (Van Tienen), Canicola (Hond Utrecht IV), Djasiman (Djasiman), Sentot (Sentot), Hebdomadis (Hebdomadis), Icterohaemorrhagiae (RGA), Copenhageni (M20), Pomona (Pomona), Pyrogenes (Salinem), Hardjo-prajitno (Norma), Hardjo-Mini (Neguita), Hardjo-CTG (local sample from Minas Gerais State, no internationally recognized) (Moreira et al. 1994), Castellonis (Castellón), Wolffi (3705)], L. biflexa [Andamana (CH11), Patoc (Patoc I)], L. borgpetersenii [Javanica (Verdrat Batavia 46/RA 94), Tarassovi (Perepelicin), Shermani (LT821), Hardjo-bovis (L171)], L. kirshneri [Cynopteri (3552C), Grippotyphosa (Moska V), Butembo (Butembo)], L. noguchii [Panama (CZ214K)] and L. weilli [Whitcombi (Whitcombi)]. Animals were considered positive when agglutination occurred at 1:100 or higher dilutions (Brasil 1995).

Bacteriology. Fragments (1.0g) of kidney (marrow) and liver from all positive and 34 negative animals, randomically selected, were separately triturated and homogenized in three tubes containing sterile saline solution each. Before culture, all samples were examined by darkfield microscopy (DFM) (Carl Zeiss, Germany) in order to visualize spirochetes. Then, by using a serial dilution technique $\left(10^{-1}, 10^{-2}\right.$ and $10^{-3}$ dilutions), samples were placed into Fletcher semisolid medium (Difco, USA), without antibiotics, added of $300 \mathrm{mg} . \mathrm{L}^{-1}$ fluorouracil (Eurofarma, Brazil) (Ris 1974), and incubated at $27^{\circ} \mathrm{C}$. For six weeks, they were evaluated by DFM once a week (Brasil 1995, Lilenbaum et al. 2007). Two aliquots $(1.0 \mathrm{~mL})$ of each homogenized tissue were frozen at $-80^{\circ} \mathrm{C}$ for genomic DNA extraction.

Polymerase Chain Reaction (PCR). The same samples were assayed by PCR. Genomic DNA was extracted from tissue samples by using a commercially available DNA extraction Kit, illustra tissue \& cells genomicPrep Mini Spin ${ }^{\circledR}$ (GE Healthcare, USA), and evaluated in a spectrophotometer (GE Healthcare, USA). Leptospira spp. DNA was amplified by the primers Lep1 (5'-GGCGGCGCGTCTTAAACATG-3') and Lep2 (5'-TTCCCCCCATTGAGCAAGATT-3') targeted to the 16S ribosomal RNA gene from Leptospira interrogans (GenBank accession n. X17547.1), in a region with 330 base pairs (bp), as described by Mérien et al. (1992). The process was performed with $25 \mu \mathrm{L}$ containing $1 \mathrm{X}$ PCR buffer (10mM Tris $\mathrm{HCl} \mathrm{pH} 8.0,50 \mathrm{mM} \mathrm{KCl}$ ), $1.5 \mathrm{mM} \mathrm{MgCl}_{2}, 200 \mu \mathrm{M} \mathrm{dNTP}$,

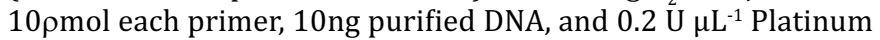
Taq DNA polymerase system (Invitrogen, Brazil). A Mastercycler gradient (Eppendorf, USA) was used with initial denaturation at $94^{\circ} \mathrm{C}$ for $3 \mathrm{~min}$, followed by 30 cycles at $94^{\circ} \mathrm{C}$ for $1 \mathrm{~min}, 63^{\circ} \mathrm{C}$ for $1 \mathrm{~min}$ and $30 \mathrm{~s}$, and a final extension at $72^{\circ} \mathrm{C}$ for $2 \mathrm{~min}$. PCR products were loaded onto $1.5 \%$ agarose gel (Invitrogen, Brazil), stained with ethidium bromide and subjected to electrophoresis in TBE buffer (0.09 M Tris-HCl, 0.09 M boric acid, 2mM EDTA, pH 8.3) for $60 \mathrm{~min}$ at $80 \mathrm{~V}$ (Electrophoresis Power Supply Model EPS 301; GE Healthcare). The amplified DNA fragments were visualized through GelDoc-It ${ }^{\mathrm{TM}}$ Imaging System, using VisionWorks ${ }^{\circledR}$ LS Software (UVP, USA).

Sequencing. The amplicons were purified by using ExoSAP-IT (USB) and the sequencing reactions were sent to the Human Genome Research Center, University of São Paulo, Brazil, and carried out on both strands through a MegaBACE ${ }^{\mathrm{TM}} 1000$ (GE Healthcare, USA). 
Sequences were analyzed by using the software BioEdit Sequence Alignment Editor 7.0.0 and compared with NCBI database by using BLAST search in GenBank (National Center for Biotechnology Information, Washington, D.C., http://www.ncbi.nlm.nih.gov/BLAST).

Statistical analysis. The association between serological results and epidemiological variables was analyzed by Chi-square or Fisher's Exact Test through the software Epi Info 3.5.1, adopting 5\% significance $(\alpha)$ (Triola 2005).

\section{RESULTS}

Seroreactive sheep accounted for 34/182 (18.68\%; CI95\% $13.70-24.98 \%)$. The serovars Copenhageni $(17 / 34 ; 50 \%$; CI95\% 33.99-66.01\%), Hardjo-prajitno (4/34; 11.76\%; CI95\% 4.81-26.74\%) and Hardjo-CTG (3/34; 8.82\%; CI95\% $3.20-23.06 \%$ ) were prevalent, with titers ranging from 100 to 400 (Table 1). No spirochetes were identified by DFM in tissue samples, but 13/34 (38.24\%; CI95\% 23.87-55.08\%) samples presented bacterial growth in Fletcher medium, of which $6 / 13(46.15 \%)$ were from the kidneys and $7 / 13$ $(53.85 \%)$ from the liver (Table 2). Twelve animals had positive culture results, since only one sheep had bacterial growth in both tissues. Leptospira spp. DNA was confirmed by PCR and sequencing in kidney samples from two animals only $(2 / 34 ; 5.88 \%)$. Both sequences had $100 \%$ homology with many Leptospira interrogans serovars (GenBank accession n. AE010300.2, FJ154557.1, FJ154552.1, FJ154550.1, FJ154549.1， FJ154545.1， FJ154543.1， FJ154542.1, EU581713.1, AB368966.1, AB368965.1, DQ991474.1, DQ991473.1, DQ991472.1, DQ991471.1, DQ991470.1, DQ991469.1, DQ991468.1, DQ991467.1, DQ991466.1, DQ991465.1, DQ991464.1, AY996793.1, AY996792.1, AY996791.1, AY996790.2, AY631894.1, AE016823.1, FJ154558.1, FJ154569.1, FJ154547.1, AM050586.1, AM050585.1, AM050584.1, AM050583.1, AM050582.1, AM050580.1, AM050571.1, AM050565.1). In addition, tissue samples from the 34 seronegative sheep were negative to the isolation and PCR. A significant association $(P \leq 0.05)$ was ob-
Table 1. Frequency of Leptospira spp. serovars in 182 studied sheep

\begin{tabular}{lccc}
\hline \multicolumn{1}{c}{ Serovar } & Positive samples & Percentage (\%) & CI95\% $^{\mathrm{a}}$ \\
\hline Copenhageni & 17 & 50.00 & $33.99-66.01$ \\
Hardjo-Prajitno & 4 & 11.76 & $4.81-26.74$ \\
Hardjo-CTG & 3 & 8.82 & $3.20-23.06$ \\
Hardjo & 2 & 5.88 & $1.80-19.16$ \\
Australis & 1 & 2.94 & $0.69-14.92$ \\
Autumnalis & 1 & 2.94 & $0.69-14.92$ \\
Butembo & 1 & 2.94 & $0.69-14.92$ \\
Djasiman & 1 & 2.94 & $0.69-14.92$ \\
Andamana & 1 & 2.94 & $0.69-14.92$ \\
Sentot & 1 & 2.94 & $0.69-14.92$ \\
Pyrogenes & 1 & 2.94 & $0.69-14.92$ \\
Pomona & 1 & 2.94 & $0.69-14.92$ \\
Total & 34 & 100.00 & - \\
\hline
\end{tabular}

${ }^{a}$ CI95\%: confidence interval of $95 \%$.

Table 2. Positive results for serology, darkfield microscopy (DFM), bacterial culture, and polymerase chain reaction (PCR)

\begin{tabular}{|c|c|c|c|c|c|c|}
\hline \multirow[t]{2}{*}{ Register $^{\mathrm{a}}$} & \multicolumn{2}{|l|}{ Serology } & \multirow[t]{2}{*}{ DFM } & \multicolumn{2}{|c|}{ Positive isolation $^{\mathrm{b}}$} & \multirow[t]{2}{*}{$\mathrm{PCR}^{\mathrm{c}}$} \\
\hline & Serovar & Titer & & Tissue & Dilution & \\
\hline A16 & Copenhageni & 200 & - & Kidney & $10^{-2}$ & - \\
\hline A20 & Copenhageni & 100 & - & Liver & $10^{-2}$ & - \\
\hline A22 & Copenhageni & 200 & - & Kidney & $10^{-2}$ & - \\
\hline $\mathrm{A} 24$ & Copenhageni & 400 & - & Liver & $10^{-2}$ & - \\
\hline A28 & Hardjo-Prajitinun & 400 & - & Liver & $10^{-2}$ & - \\
\hline A31 & Hardjo-Prajitinun & 400 & - & Liver & $10^{-1}$ & - \\
\hline A36 & Hardjo-CTG & 400 & - & Kidney & $10^{-2}$ & - \\
\hline \multirow[t]{2}{*}{ A64 } & Hardjo & 200 & - & Kidney & $10^{-3}$ & - \\
\hline & & & - & Liver & $10^{-2}$ & - \\
\hline B1 & Sentot & 200 & - & Kidney & $10^{-2}$ & + \\
\hline B32 & Hardjo-CTG & 200 & - & Kidney & $10^{-2}$ & + \\
\hline B61 & Copenhageni & 200 & - & Liver & $10^{-2}$ & - \\
\hline B67 & Copenhageni & 200 & - & Liver & $10^{-2}$ & - \\
\hline
\end{tabular}

${ }^{\mathrm{a}} \mathrm{A}=$ slaughterhouse $\mathrm{A} ; \mathrm{B}=$ slaughterhouse $\mathrm{B} ;{ }^{\mathrm{b}}$ Presence of non-specific bacterial growth; ' Polymerase Chain Reaction (Lep1:Lep2).

served among serological results and breed, municipality and slaughterhouses (Table 3). The last variable presented $\mathrm{OR}=0.5$ (0.2-1.1) for slaughterhouse A (23.9\%; CI95\% 16.4-33.6\%), relative to slaughterhouse B (13.3\%; CI95\% 7.8-21.9\%).

Table 3. Association between epidemiological and serological results for sheep from both slaughterhouses

\begin{tabular}{|c|c|c|c|c|c|c|}
\hline & Variable & Tested & Positive & Positive (\%); CI95\%a & OR (CI95\%) & $P^{\mathrm{b}}$ \\
\hline \multirow[t]{2}{*}{ Sex } & Male & 101 & 18 & $17.8 ; 11.6-26.4$ & \multirow{2}{*}{$1.1(0.5-2.4)$} & \multirow{2}{*}{0.44} \\
\hline & Female & 81 & 16 & $19.8 ; 12.6-29.7$ & & \\
\hline \multirow[t]{4}{*}{ Age (years) } & $0-1$ & 112 & 19 & $17.0 ; 11.2-25.0$ & \multirow{4}{*}{-} & \multirow{4}{*}{0.81} \\
\hline & $>1-2$ & 57 & 12 & $21.1 ; 12.5-33.4$ & & \\
\hline & $>2-3$ & 12 & 3 & $25.0 ; 09.1-53.8$ & & \\
\hline & $>3$ & 1 & 0 & $00.0 ; 00.0-00.0$ & & \\
\hline \multirow[t]{4}{*}{ Breed } & Mixed breed & 30 & 9 & $30.0 ; 16.7-48.0$ & \multirow{4}{*}{-} & \multirow{4}{*}{0.01} \\
\hline & Merin & 133 & 18 & $13.5 ; 08.8-20.4$ & & \\
\hline & Santa Inês & 16 & 5 & $31.3 ; 14.2-56.0$ & & \\
\hline & Other & 3 & 2 & $66.7 ; 19.4-93.2$ & & \\
\hline \multirow[t]{2}{*}{ Breeding system } & Hemi-intensive & 45 & 6 & $13.3 ; 06.3-26.3$ & \multirow{2}{*}{$1.7(0.6-4.3)$} & \multirow{2}{*}{0.20} \\
\hline & Extensive & 137 & 28 & $20.4 ; 14.6-28.0$ & & \\
\hline \multirow[t]{2}{*}{ State } & $\mathrm{RS}^{\mathrm{c}}$ & 137 & 28 & $20.4 ; 14.6-28.0$ & \multirow{2}{*}{$0.6(0.2-1.6)$} & \multirow{2}{*}{0.20} \\
\hline & $\mathrm{SP}^{\mathrm{d}}$ & 45 & 6 & $13.3 ; 06.3-26.3$ & & \\
\hline \multirow[t]{5}{*}{ Municipality } & Santana do Livramento ${ }^{c}$ & 76 & 21 & $27.6 ; 18.9-38.6$ & \multirow{5}{*}{-} & \multirow{5}{*}{0.01} \\
\hline & Uruguaiana $^{c}$ & 61 & 7 & $11.5 ; 05.7-21.9$ & & \\
\hline & São Manuel ${ }^{\mathrm{d}}$ & 27 & 4 & $14.8 ; 06.1-32.7$ & & \\
\hline & Duartina $^{\mathrm{d}}$ & 15 & 0 & $00.0 ; 00.0-00.0$ & & \\
\hline & Itapirad $^{\mathrm{d}}$ & 3 & 2 & $66.7 ; 19.4-93.2$ & & \\
\hline \multirow[t]{2}{*}{ Slaughterhouse } & A & 92 & 22 & $23.9 ; 16.4-33.6$ & \multirow{2}{*}{$0.5(0.2-1.1)$} & \multirow{2}{*}{0.05} \\
\hline & $\mathrm{B}$ & 90 & 12 & $13.3 ; 07.8-21.9$ & & \\
\hline
\end{tabular}

${ }^{\mathrm{a}} \mathrm{CI} 95 \%=$ confidence interval of $95 \%$; ${ }^{\mathrm{b}} P=P$ value to $\alpha, 5 \%$; ${ }^{\mathrm{c}} \mathrm{RS}=$ State of Rio Grande do Sul; ${ }^{\mathrm{d}} \mathrm{SP}=$ State of São Paulo. 


\section{DISCUSSION}

The prevalence identified in this study was higher than those observed by Rocha et al. (1998) $(175 / 5298,3.3 \%)$ in Portugal; Zamora et al. (1999) $(36 / 329,5.7 \%)$ in 11 selected sheep farms from Chile; Ciceroni et al. (2000) (19/313, $6.1 \%)$ in 26 localities from Alto Adige, Austria; Cerri et al. (2003) $(132 / 1088,12.1 \%)$ in labs from Italy; Dorjee et al. (2008) $(157 / 2758,5.7 \%)$ in slaughtered sheep from New Zealand; and Lilenbaum et al. (2009) (40/292, 13.7\%) in sheep flocks from Rio de Janeiro, Brazil.

Sheep serum samples presented high prevalence to the serovars Copenhageni, Hardjo-Prajitno and Hardjo-CTG, different from those observed by Rocha (1998), reporting the serovars Canicola, Pomona and Cynopteri. The crossed reaction between Hardjo-Prajitno and Hardjo-CTG can occur and must be considered a possibility in this study. These serovars are highly important to herbivorous species, causing abortion (Suepaul et al. 2011). Most of positive animals $(28 / 137,20.4 \%)$ were bred extensively. This value is referent only to the animals bred extensively (reagents/ total of animals bred extensively, percentage of reagents). In this case, other herbivorous reservoirs can keep the bacteria in the environment, acting as a source of infection for these sheep. The prevalence in extensive breeding system is present in the south region of Brazil (Herrmann et at. 2004), mainly in Santana do Livramento $(21 / 76,27.6 \%)$ and Uruguaiana $(7 / 61,11.5 \%)$ municipalities.

Once infected, both male and female sheep can present leptospires in the renal tissue, and reproductive system (Leon-Vizcaino et al. 1985, Lilenbaum et al. 2008), as experimentally observed for the serovars Hardjo-bovis (Farina et al. 1996) and Hardjo (Cerri et al. 1996), emphasizing the high importance of sheep as a carrier of these serovars. Lilenbaum et al. (2009) observed a high frequency of the serovars Sejroe $(17 / 40,42.5 \%)$, Shermani $(11 / 40,27.5 \%)$, Grippotyphosa $(4 / 40,10 \%)$, Icterohaemorrhagiae $(4 / 40$, $10 \%)$ and Autumnalis $(3 / 40,7.5 \%)$, which are common in humans, dogs and wild rodents. Besides serology, those authors detected positive results by DFM and PCR in four cases only. No sample was positive in the bacteriological culture of urine from sheep, since the cultivation of leptospires from urine is difficult and time-consuming. In addition, the culture may present low sensitivity due to inherent methodological difficulties, including fastidiousness regarding growth in an artificial medium, contamination and intermittent bacterial shedding (Cerri et al. 1996, Lilenbaum et al. 2007). The combined use of MAT as a screening test followed by urine PCR for leptospiral DNA direct detection was adequate to identify carriers among goats and sheep (Lilenbaum et al. 2009).

Epidemiological factors can contribute to keep the bacteria in the environment. The extensive breeding system is an important factor to be considered (Herrmann et at. $2004)$, although it was not significant in this study $(P>0.05)$. Lacerda et al. (2008) observed that the bacterial burden in Leptospira infection during periods of normal or high rainfall may be overestimated in the northeast region of Brazil. Regarding to the breed, significative association $(P \leq 0.05)$ was observed, presenting higher prevalence to mixed breed and Santa Inês than the others, all bred in São Paulo State. These two breed are usually bred as hemi-intensive breed system, mainly in São Paulo State, and located in a region with a high pluviometric index, which favor the occurrence of leptospirosis. Analyzing the municipalities, significative association $(P \leq 0.05)$ was observed, mainly in Itapira, SP $(2 / 3,66.7 \%)$ and Santana do Livramento $(21 / 76,27.6 \%)$. Itapira presented low number of samples assayed, which compromises the significance of the analysis. In other way, Santana do Livramento, RS, present high pluviometric index and the possibility of sheep-cattle mixed breeding, possible source of infection for sheep.

Zakeri et al. (2010) identified by nested PCR Leptospira spp. DNA in 13/75 (17.33\%) serum samples from sheep in Iran, of which $11 / 13(84.6 \%)$ were L. interrogans and $2 / 13$ $(15.4 \%)$ were $L$. wolffi. Leptospirosis is an occupational and recreational disease. Farmers and slaughterhouse workers can be infected by handling animals and their blood and tissues and not using personal protective equipment, respectively. Lesions in the hands are important entrance points of this bacterium into the host. L. interrogans serovar Hardjo was found in the kidneys of three seropositive slaughtered ewes but not in their uterus or salpinges (Cerri et al. 1996).

Two animals (B1 and B32) had positive samples isolated from the kidneys, according to DFM and PCR, corroborating the observations of Silva et al. (2007), in Pelotas Municipality, Rio Grande do Sul State, Brazil, that reported for the first time the isolation of L. noguchii serovar Autumnalis from one kidney from sheep, to the 16S rRNA gene sequence.

Dorjee et al. (2008) observed high titers to the serovars Hardjo-bovis (33\%) and Pomona (4\%), also common in herbivores and rodents, respectively. Isolation was obtained from kidneys of $8 / 32$ (22\%, positive to Hardjo-bovis), $1 / 6$ (17\%, positive to Pomona) and 5/499 (1\%, seronegative) sheep. Those authors concluded that the isolation from seropositive animals presented 21.7 higher probability to be positive than that from seronegative ones. That study evidenced a definite risk due to the occupational exposure of workers from a sheep-only slaughterhouse to the two most pathogenic Leptospira spp. serovars in New Zealand.

The present study also shows a significant difference $(P \leq 0.05)$ between both slaughterhouses based on sheep seropositive samples. Slaughterhouse A, received more animals from RS than SP and had 0.5 higher probability to present a positive animal than slaughterhouse B. Thus, it was in contact with the slaughterhouse workers, which represents the possibility of risk for both slaughterhouses A and $B$, mainly in the former, where a worker became infected by this bacterium due to sheep tissue handling. These data confirm the findings emphasizing the importance of leptospirosis as an occupational disease, such as the results obtained by Benschop et al. (2009), who detected 23/242 $(9.5 \%)$ seropositive workers in a sheep slaughterhouse from New Zealand, suggesting a significant exposure of workers to leptospirosis from sheep in the studied slaughterhouse.

Based on the increasing consumption of ovine meat in the last years, with world exportations of 841,862 tons of 
fresh meat until 2002, these animals require special attention regarding zoonosis control (Bharadwaj 2004).

Prescott (1992) detected positivity to leptospirosis in $11 / 63(17.5 \%)$ veterinarians (ten to Bratislava and one to Icterohaemorrhagiae) and 11/92 (12.0\%) slaughterhouse workers (eight to Bratislava and three to Icterohaemorrhagiae), suggesting that Bratislava is the most important pathogenic leptospiral serovar for these occupational risk groups. The importance of this serovar in domestic animals has been identified only in the recent years.

Sheep treatment and vaccination, as well as control of rodents, can result in the control of leptospirosis in the studied region, especially for the safety of slaughterhouse workers. The adoption of individual protective equipments (IPE) may help, but alerting these people is the most important measure to assure the correct use of IPE. Sheep are important Leptospira spp. reservoirs for humans and other domestic animals and can be transmitted to slaughterhouse workers mainly by the handling of blood and visceral tissues like kidneys and liver without IPE or when it is inadequately used.

Thus, preventive actions directed to sheep, recognized as reservoirs of leptospires, are extremely necessary in slaughterhouses, since leptospirosis is one of the most important emerging and re-emerging zoonosis.

Acknowledgements.- To School of Veterinary Medicine and Animal Science, Unesp, for the financial and logistical support, and to São Paulo State Association of Sheep Breeders (ASPACO) for the help with the animal data.

\section{REFERENCES}

Benschop J., Heuer C., Jaros P., Collins-Emerson J., Midwinter A. \& Wilson P. 2009. Sero-prevalence of leptospirosis in workers at a New Zealand slaughterhouse. N. Z. Med. J. 122(1307):39-47.

Bharadwaj R. 2004. Leptospirosis, a reemerging disease? Indian J. Med. Res. 120:136-138.

Bharti A.R. 2003. Leptospirosis: a zoonotic disease of global importance. Lancet Infect. Dis. 3:757-771.

Brasil 1995. Manual de Leptospirose. $2^{\underline{a}}$ ed. Coordenação de Controle de Zoonoses e Animais Peçonhentos, Fundação Nacional de Saúde, Centro Nacional de Epidemiologia, Ministério da Saúde, Brasília. 98p.

Brasil 2009. Ministério da Agricultura, Pecuária e Abastecimento. Serviço de Inspeção Sanitária Federal. Quantidade de abate estadual por ano e espécie. Disponível em: <extranet.agricultura.gov.br/sigsif_cons/!ap_ abate_estaduais_cons>. Acesso em: 20 jan. 2009.

CDC 2008. Epi Info 3.5.1. Available in <www.cdc.gov/epiinfo> Access on Aug. 14, 2009.

Cerri D., Nuvoloni R., Ebani V., Pedrini A., Mani P., Andreani E. \& Farina, R. 1996. Leptospira interrogans serovar Hardjo in the kidneys and genital tracts of naturally infected sheep. New Microbiol. 19(2):175-178.

Cerri D., Ebani V., Fratini F., Pinzauti P. \& Andreani E. 2003. Epidemiology of leptospirosis: observations on serological data obtained by a diagnostic laboratory for leptospirosis from 1995 to 2001. New Microbiol. 26(4):383-389.

Ciceroni L., Lombardo D., Pinto A., Ciarrocchi S. \& Simeoni J., 2000. Prevalence of antibodies to Leptospira serovars in sheep and goats in Alto Adige-Soul Tyrol. J. Vet. Med. B, Infect. Dis. Vet. Public Health 47(3):217-223.

Dorjee S., Heuer C., Jackson R., West D.M., Collins-Emerson J.M., Midwinter A.C. \& Ridler A.L. 2008. Prevalence of pathogenic Leptospira spp. in sheep in a sheep-only abattoir in New Zealand. N. Z. Vet. J. 56(4):164-170.

Dorjee S., Heuer C., Jackson R., West D.M., Collins-Emerson J.M., Midwinter A.C. \& Ridler A.L., 2011. Assessment of occupational exposure to leptospirosis in a sheep-only abattoir. Epidemiol. Infect. 139:797-806.

Farina R., Cerri D., Renzoni G., Andreani E., Mani P., Ebani V. Pedrini A. \&
Nuvoloni R. 1996. Leptospira interrogans in the genital tract of sheep: research on ewes and rams experimentally infected with serovar Hardjo (Hardjobovis). New Microbiol. 19(3):235-242.

Herrmann G.P., LageI A.P., MoreiraI E.C., HaddadI J.P.A., ResendeI J.R., Rodrigues R.O., Leite R.C., 2004. Soroprevalência de aglutininas anti-Leptospira spp. em ovinos nas Mesorregiões Sudeste e Sudoeste do Estado Rio Grande do Sul, Brasil. Ciencia Rural 34(2):443-448.

Horsch F. 1999. Leptospirose, p.305-326. In: Beres J. (Ed.), Doenças Infecciosas em Animais Domésticos. Roca, São Paulo.

Lacerda H.G., Monteiro G.R., Oliveira C.C.G., Suassuna F.B., Queiroz J.W., Barbosa J.D.A., Martins D.R., Reis M.G., Ko A.I. \& Jeronimo S.M.B. 2008. Leptospirosis in a subsistence farming community in Brazil. Trans. R. Soc. Trop. Med. Hyg. 102:1233-1238.

Leon-Vizcaino L., Mendoza M.H. \& Garrido F. 1987. Incidence of abortions caused by leptospirosis in sheep and goats in Spain. Comp. Immunol., Microbiol. Infect. Dis. 10:149-153.

Lilenbaum W., Morais Z.M., Gonçales A.P., Souza G.O., Richtzenhain L. \& Vasconcellos S.A. 2007. First isolation of leptospires from dairy goats in Brazil. Braz. J. Microbiol. 38:507-510.

Lilenbaum W., Varges R., Brandão F.Z., Cortez A., de Souza S.O., Brandão P.E., Richtzenhain L.J. \& Vasconcellos S.A. 2008. Detection of Leptospira spp. in semen and vaginal fluids of goats and sheep by polymerase chain reaction. Theriogenology 69:837-842.

Lilenbaum W., Varges R., Ristow P., Cortez A., de Souza S.O., Richtzenhain L.J. \& Vasconcellos S.A. 2009. Identification of Leptospira spp. carriers among seroreactive goats and sheep by polymerase chain reaction. Res. Vet. Sci. 87:16-19.

Martins G., Penna B., Hamond C., Leite R.C., Silva A., Ferreira A., Brandão F., Oliveira F. \& Lilenbaum W. 2011. Leptospirosis as the most frequent infectious disease impairing productivity in small ruminants in Rio de Janeiro, Brazil. Trop. Anim. Health. Prod. (In publication)

Mérien F., Amouriaux P., Perolat P., Baranton G. \& Saint Girons I. 1992. Polymerase Chain Reaction for detection of Leptospira spp. in clinical samples. J. Clin. Microbiol. 30(9):2219-2224.

Moreira E.C., 1994. Avaliação de métodos para erradicação de leptospirose em bovinos leiteiros. Tese de Doutorado em Medicina Veterinária, Escola de Medicina Veterinária, Universidade Federal de Minas Gerais, Belo Horizonte. 94p.

Prescott J. 1992. Prevalence of antibody to leptospiral serovars in veterinarians and slaughterhouse workers in Nova Scotia. Can. Vet. J. 33:276.

Ris D.R. 1974. Limitations of the use of 5-fluorouracil as a selective agent for the isolation of Leptospirae. Appl. Microbiol. 27:270-271.

Rocha T. 1998. A review of leptospirosis in faro animals in Portugal. Rev. Sci. Tech. 17(3):699-712.

Sacsaquispe-Contreras R., Glenny, A.M. \& Céspedes, Z.M., 2003. Estudio preliminar de leptospirosis en roedores y canes en Salitral, Piura - 1999. Revta Peru. Med. Exp. Salud Pública 20(1):39-40.

Silva E.F., Brod C.S., Cerqueira G.M., Bourscheidt D., Seyffert N., Queiroz A., Santos C.S., Ko A.I. \& Dellagostin O.A. 2007. Ocorrência de aglutininas anti-Leptospira em ovinos do estado do Rio Grande do Norte, Brasil solation of Leptospira noguchii from sheep. Vet. Microbiol. 121(1/2):144-149.

Sorio A. \& Rasi L. 2010. Ovinocultura e abate clandestino: um problema fiscal ou uma solução de mercado? Revta Política Agric. 19(1):71-83.

Suepaul S.M., Carrington, C.V., Campbell M., Borde G. \& Adesiyun A.A. 2011. Seroepidemiology of leptospirosis in livestock in Trinidad. Trop. Anim. Health Prod. 43:367-375.

Triola M.F. 2005. Introdução à Estatística. LTC, Rio de Janeiro. 656p.

Trubo R. 2001. Leptospira brings fresh challenge to adventure sports. Lancet Infect. Dis. 1:73.

Zakeri S., Khorami N., Ganji Z.F., Sepahian N., Malmasi A.A., Gouya M.M. \& Djadid N.D. 2010. Leptospira wolffii, a potential new pathogenic Leptospira species detected in human, sheep and dog. Infect., Genet. Evol. 10:273-277.

Zamora J., Riedemann S. \& Tadich N. 1999. A serological survey of leptospirosis in sheep in Chile. Revta Latinoam. Microbiol. 41(2):73-76. 